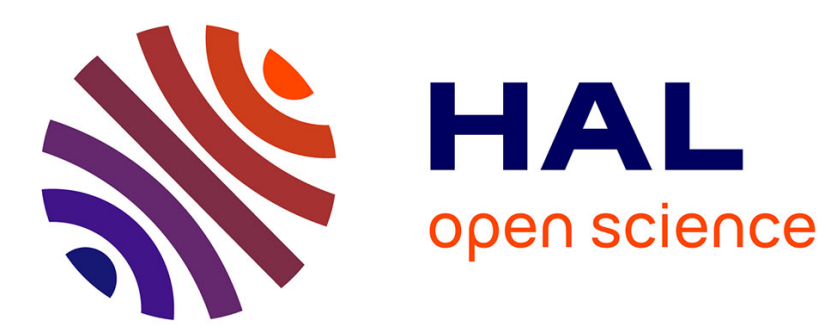

\title{
Time scales of melt extraction revealed by distribution of lava composition across a ridge axis
}

Carole Cordier, Mathieu Benoit, Christophe C Hémond, J. Dyment, Bernard Le Gall, Anne Briais, M. Kitazawa

\section{- To cite this version:}

Carole Cordier, Mathieu Benoit, Christophe C Hémond, J. Dyment, Bernard Le Gall, et al.. Time scales of melt extraction revealed by distribution of lava composition across a ridge axis. Geochemistry, Geophysics, Geosystems, 2010, 11, pp.Q0AC06. 10.1029/2010GC003074 . insu-00563239

\section{HAL Id: insu-00563239}

https://hal-insu.archives-ouvertes.fr/insu-00563239

Submitted on 15 Feb 2011

HAL is a multi-disciplinary open access archive for the deposit and dissemination of scientific research documents, whether they are published or not. The documents may come from teaching and research institutions in France or abroad, or from public or private research centers.
L'archive ouverte pluridisciplinaire HAL, est destinée au dépôt et à la diffusion de documents scientifiques de niveau recherche, publiés ou non, émanant des établissements d'enseignement et de recherche français ou étrangers, des laboratoires publics ou privés. 
Published by AGU and the Geochemical Society

ISSN: $1525-2027$

\section{Click \\ Here \\ Full \\ Article}

\section{Time scales of melt extraction revealed by distribution of lava composition across a ridge axis}

\section{Carole Cordier}

Domaines Océaniques, UMR 6538, Université Européenne de Bretagne, Université de Brest, IUEM, CNRS, Place N. Copernic, F-29280 Plouzané, France

Now at Museo Nazionale dell'Antartide, Via Laterina 8, I-53100 Siena, Italy (cordier@unisi.it)

\section{Mathieu Benoit}

Domaines Océaniques, UMR 6538, Université Européenne de Bretagne, Université de Brest, IUEM, CNRS, Place N. Copernic, F-29280 Plouzané, France

Now at Dynamique Terrestre et Planétaire, OMP, 14 avenue Edouard Belin, F-31400 Toulouse, France (benoit@dtp.obs-mip.fr)

\section{Christophe Hémond}

Domaines Océaniques, UMR 6538, Université Européenne de Bretagne, Université de Brest, IUEM, CNRS, Place N. Copernic, F-29280 Plouzané, France

\section{Jérôme Dyment}

Equipe Géosciences Marines, UMR 7154, IPGP, CNRS, 4 Place Jussieu, F-75005 Paris, France (jdy@ipgp.jussieu.fr)

\section{Bernard Le Gall}

Domaines Océaniques, UMR 6538, Université Européenne de Bretagne, Université de Brest, IUEM, CNRS, Place N. Copernic, F-29280 Plouzané, France

\section{Anne Briais}

Dynamique Terrestre et Planétaire, OMP, 14 avenue Edouard Belin, F-31400 Toulouse, France (anne.briais@dtp.obs-mip.fr)

\section{Mitsuko Kitazawa}

Equipe Géosciences Marines, UMR 7154, IPGP, CNRS, 4 Place Jussieu, F-75005 Paris, France

Now at Schlumberger House, 23 Solbraaveien, Oslo N-1383, Norway

[1] Temporal fluctuations of magmatic processes during the last $800 \mathrm{kyr}$ have been investigated for the slow spreading Central Indian Ridge. The fluctuations are recorded by variations in lava chemistry along a $40 \mathrm{~km}$ long profile across the ridge. The temporal relations of the basalts were accurately restored using magnetic microanomalies. We report on the occurrence of ancient lavas enriched in incompatible elements whereas on-axis samples are typical normal mid-ocean ridge basalts. The enriched lavas are symmetrically distributed on either side of the ridge, implying that enriched melts reached the seafloor at intervals of about 150-200 kyr. This periodicity is viewed as a characteristic time scale in the aggregation processes of the melts produced from a heterogeneous mantle source. Geochemical variations of zero-age mid-ocean 
ridge basalts may primarily reflect such periodic processes rather than the spatial distribution of mantle heterogeneities.

Components: 5500 words, 5 figures, 1 table.

Keywords: spreading ridge; basaltic lavas; mantle processes.

Index Terms: 1032 Geochemistry: Mid-oceanic ridge processes (3614); 1037 Geochemistry: Magma genesis and partial melting (3619); 1021 Geochemistry: Composition of the oceanic crust.

Received 9 February 2010; Revised 11 May 2010; Accepted 22 May 2010; Published 10 July 2010.

Cordier, C., M. Benoit, C. Hémond, J. Dyment, B. Le Gall, A. Briais, and M. Kitazawa (2010), Time scales of melt extraction revealed by distribution of lava composition across a ridge axis, Geochem. Geophys. Geosyst., 11, Q0AC06, doi:10.1029/2010GC003074.

Theme: Geochemical Heterogeneities in Oceanic Island Basalt and Mid-ocean Ridge Basalt Sources: Implications for Melting Processes and Mantle Dynamics

Guest Editors: C. Beier and P. Asimow

\section{Introduction}

[2] The chemical diversity recorded by mid-ocean ridge basalts (MORB) results from multiple factors including (1) degree of decompression melting; (2) mantle source heterogeneities; (3) extraction, migration, and interaction of melts within the mantle; and (4) melt differentiation in crustal reservoirs. These processes are relatively well documented from compositional variations observed in zero-age basalts collected along ridge axes. Recently, significant chemical variations of the oceanic rocks have been evidenced along cross-ridge sampling profiles. They result from long-term variations of temperature and composition of the upwelling mantle below very slow spreading ridges [Bonatti et al., 2003; Cipriani et al., 2009; Coogan et al., 2004]. However, little is known about shorter-scale temporal variations of magmatic processes during ongoing accretion. This is due to a lack of systematic and high-resolution sampling across ridge axes. In this study, we present variations of MORB chemistry across the Central Indian Ridge (CIR) obtained through a high-resolution sampling profile conducted during the GIMNAUT cruise (2000).

\section{Central Indian Ridge at $19^{\circ} \mathrm{S}$}

[3] The spreading segment covers $300 \mathrm{~km}$ between the Marie-Céleste and the Egeria transform faults along which the ridge axis is offset by $300 \mathrm{~km}$ toward the Réunion Island (Figure 1a). Bathymetry [Briais, 1995], seismicity [Hanson and Bowman, 2005] and gravimetry [Sandwell and Smith, 1997]

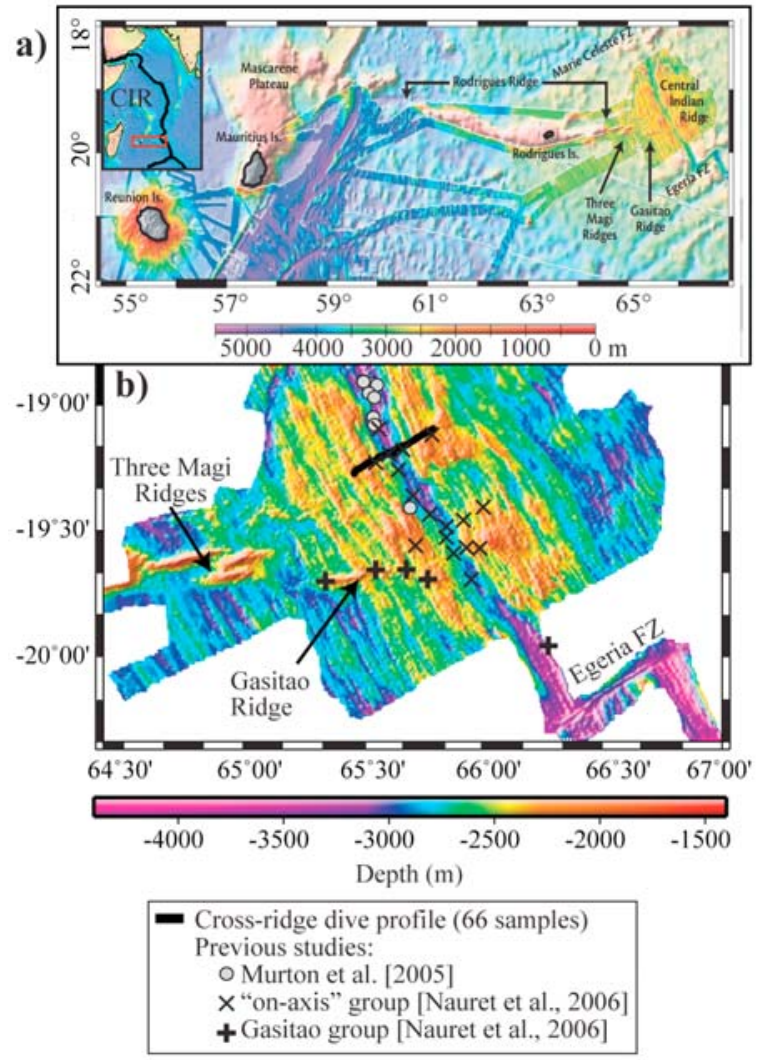

Figure 1. Location of the profile across the CIR surveyed during the GIMNAUT cruise. Dark colors show multibeam bathymetric data, and pale colors show the satellite-derived bathymetry [Smith and Sandwell, 1997]. (a) Location of the studied ridge area [Dyment et al., 2007]. (b) Bathymetric map of the CIR axis and surrounding off-axis volcanic ridges [Dyment et al., 1999] with position of the profile and previously studied samples. 
suggest a hot underlying asthenosphere and a high magma supply given the slow full spreading rate (42 mm/yr [DeMets et al., 1990]). At a latitude of $19^{\circ} 40^{\prime} \mathrm{S}$, the axis meets a $600 \mathrm{~km}$ long E-W trending volcanic lineament consisting of the Gasitao, the Three Magi, and the Rodrigues Ridges, extending westward to the Mascarene Plateau (Figure 1a). The composition of on-axis lavas [Murton et al., 2005; Nauret et al., 2006] and basalts of the Gasitao [Nauret et al., 2006] and Rodrigues [Mellor, 1998] Ridges reveals an enriched underlying mantle when compared to depleted MORB mantle. The contamination of the CIR mantle is partly explained by the influence of the Réunion plume [Mahoney et al., 1989; Murton et al., 2005]. However, isotope compositions of on- and off-axis basalts (Gasitao Group (Figure 1b)) suggest the existence of a distinct enriched end-member [Nauret et al., 2006] also involved in the genesis of the Rodrigues Island lavas.

\section{Methods}

[4] Nine Nautile dives were dedicated to geological observations, magnetic measurements, and sample collection. Running perpendicularly to the ridge axis at latitude $19.2^{\circ} \mathrm{S}$, the resulting profile covers $40 \mathrm{~km}$ on both flanks of the CIR, from the axial valley to the Brunhes-Matuyama isochron (Figures 1 and 2a).

\subsection{Use of High-Resolution Magnetic Anomalies as a Geochronological Tool}

[5] Previous studies of high-resolution near-seafloor magnetic anomalies acquired at different spreading centers [Gee et al., 2000; Honsho et al., 2009] show that high-resolution magnetic anomalies are recorded in the oceanic crust and are related to temporal variations of geomagnetic intensity. With this in mind, across-axis near-seafloor magnetic anomalies covering the last $800 \mathrm{kyr}$ period were acquired during the Nautile dives. They have been processed and inverted to absolute magnetization following the method developed by Honsho et al. [2009]. The deduced magnetization represents a value for the oceanic crust averaged over a $32 \mathrm{~m}$ interval along the profile (Figure 2b). Consecutive sequences of microanomalies identified from the magnetization profile match the geomagnetic paleointensity curve SINT 800 over intervals of hundreds of thousands of years [Guyodo and Valet, 1999; Suganuma et al., 2008]. This similarity suggests that no significant off-axis volcanism has perturbed the magnetization signal. Indeed, the magnetic signature of a young lava coating would prevail on the recorded signal, as expected for off-axis volcanics because they are closer to the magnetometer. Lack of off-axis volcanism is reinforced by the interpretation of EM12-D backscatter images acquired during the cruise [Briais et al., 2001] and the good agreement between the magnetic and preliminary $\mathrm{K}-\mathrm{Ar}$ ages obtained on a few samples (C. Hémond, unpublished data, 2008). Thus, ages of the seafloor were restored from the magnetization profile, providing a time scale that we used to investigate variations in magmatic processes (Figure $2 b$ ). The magnetization-derived ages differ in average by only $8 \%$ with respect to those calculated by a linear interpolation between the spreading axis and the Brunhes-Matuyama boundary defined on the sea surface magnetic anomalies (Figure 2b). Discrepancies are interpreted as resulting from small ridge jumps within the neovolcanic zone, causing short crust repetitions that perturb the symmetrical accretion and that have been taken into account to construct the time-converted profile (Figure $2 \mathrm{~b}$ ).

\subsection{Lava Geochemistry}

[6] Sixty-five out of sixty-six collected lavas were analyzed for major and trace elements (IUEM, Domaines Océaniques, Brest, France). Based on their freshness, their trace element characteristics, and their location along the profile 25 samples were selected and analyzed for $\mathrm{Sr}-\mathrm{Nd}$ isotope ratios. Methodologies and results are presented in Text S1 and Data Set S1 in the auxiliary material, respectively. ${ }^{1}$

\section{Results}

\subsection{Morphotectonic Evolution Along the Profile}

[7] The volcanic edifice within the $3000 \mathrm{~m}$ deep axial trough coincides with the position of the Central Anomaly Magnetic High and is thus ascribed a zero age (Figures $2 \mathrm{a}$ and $2 \mathrm{~b}$ ). The graben-like morphology of the axis precludes the transport of axial lavas down to the flanks of the ridge and their emplacement off-axis, contrary to the case of dome-shaped fast spreading ridges [Soule et al., 2005]. Off the axial trough, the volcanic basement is covered by pelagic sediments and crops out either along inward facing ridge-parallel fault scarps or

\footnotetext{
${ }^{1}$ Auxiliary material data sets are available at ftp://ftp.agu.org/ apend/gc/2010gc003074. Other auxiliary material files are in the HTML.
} 


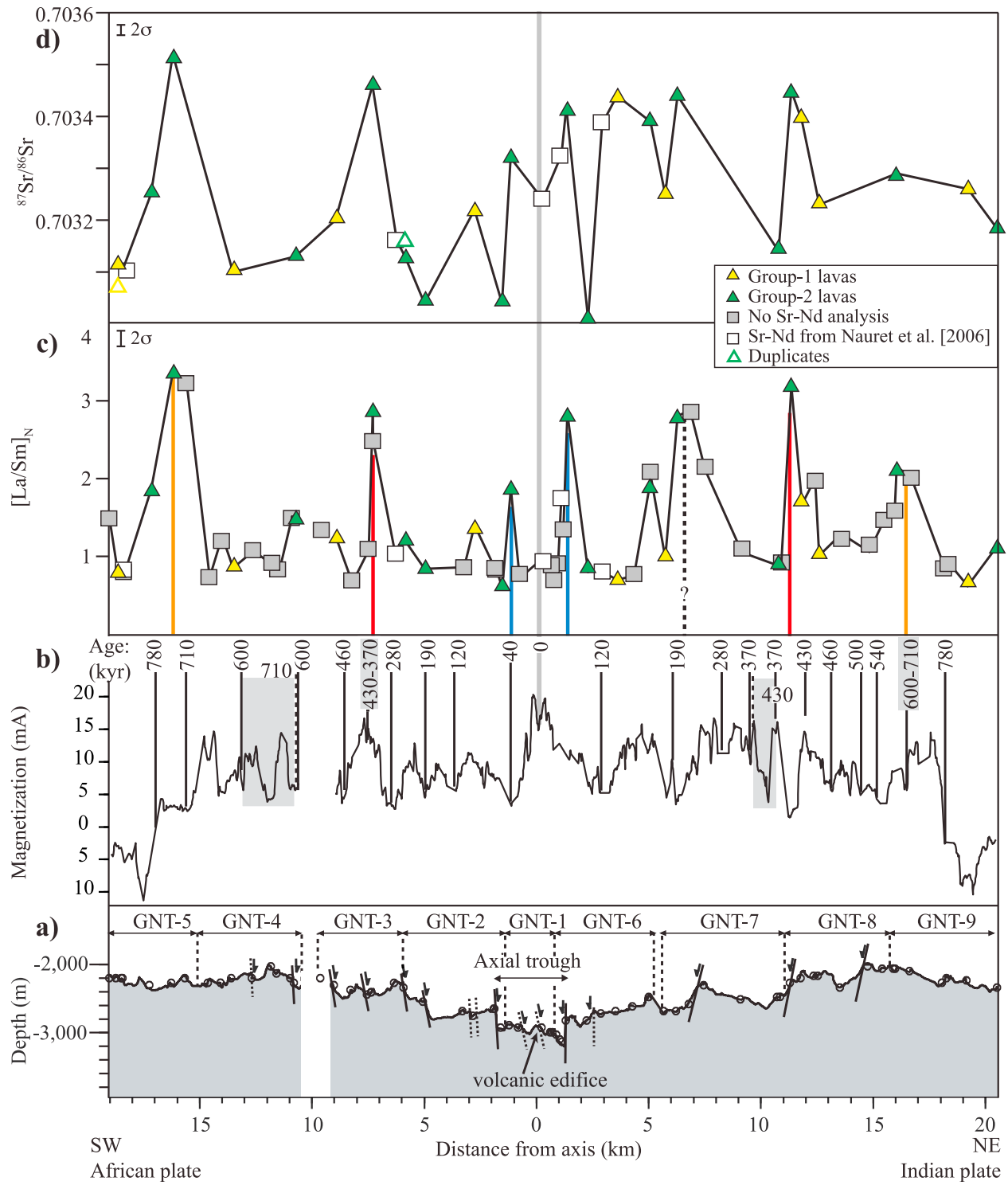

Figure 2. Distribution of lava compositions across the CIR. (a) Synthetic geological cross-axis profile constructed after dive observations with solid circles indicating sample positions. (b) Crustal ages obtained from the magnetization profile by comparison of the magnetic microanomalies with the relative paleointensity curve SINT 800 for the Brunhes period [Guyodo and Valet, 1999; Suganuma et al., 2008]. Repetitions and lacks of crust portions (dashed areas) from 370 to $430 \mathrm{kyr}$ and 600 to $700 \mathrm{kyr}$ reflect ridge jumps. (c and d) $[\mathrm{La} / \mathrm{Sm}]_{\mathrm{N}}$ and ${ }^{87} \mathrm{Sr} /{ }^{86} \mathrm{Sr}$ fluctuations versus distance to the ridge axis. Additional isotope data measured on samples from the same dives by Nauret et al. [2006] are used to fill the gap of our isotope data set. The ${ }^{87} \mathrm{Sr}{ }^{86} \mathrm{Sr}$ ratios of two samples for which we duplicated leaching, elution, and isotope analysis are plotted. The standard deviation is $2 \sigma$.

at the top of ancient volcanic domes (Figure 2a). These outcrops permitted the sampling of the volcanic crust with a mean interval of $500 \mathrm{~m}$. A structural asymmetry characterizes the flanks of the ridge axis (Figure 2a). Namely, lesser fault scarps with higher amplitudes (up to $450 \mathrm{~m}$ ) dissect the eastern side than the western side. The basement is composed of pillow lava and sheet flows, together with sparse volcanic breccias and thin $(<1 \mathrm{~m})$ steeply dipping axis-parallel dikes.
Observations from the submersible reveal that lava flows are rapidly eroded off axis and lose their magmatic ornamentation within the first two kilometers. Further off axis, a progressive modification of the seafloor was observed: the sediment abundance monotonically increases; the glass abundance and freshness decrease while the degree of alteration of the lava flows increases. These geological observations support the regular spreading history suggested by magnetization 


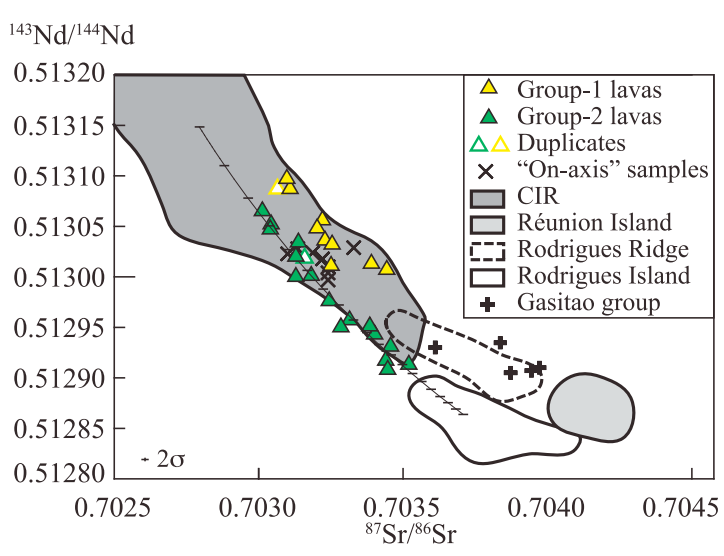

Figure 3. The ${ }^{143} \mathrm{Nd} /{ }^{144} \mathrm{Nd}$ and ${ }^{87} \mathrm{Sr} /{ }^{86} \mathrm{Sr}$ ratios of the GIMNAUT lavas compared with isotope values of basalts collected along the CIR axis and on surrounding volcanic ridges and islands [Bosch et al., 2008; Baxter et al., 1985; Mahoney et al., 1989; Nauret et al., 2006; Pietruszka et al., 2009; Vlastélic et al., 2009]. All literature isotopic data have been corrected relative to the same values for NBS987 $\left({ }^{87} \mathrm{Sr} /{ }^{86} \mathrm{Sr}=0.710240\right)$ and La Jolla $\left({ }^{143} \mathrm{Nd} /{ }^{144} \mathrm{Nd}=0.511872\right)$ for direct comparison with our data. The standard deviation is $2 \sigma$. Ticks on the mixing line correspond to increments of 5\%. End-member compositions are listed in Table 1.

data, without disturbance by younger fissural volcanism or seamount-like structures. Most of the flows sampled along the profile have thus been emplaced along the ridge axis, before drifting progressively away on both sides of the ridge.

\subsection{Geochemical Evolution Along the Profile}

[8] The basalts are quite homogeneous in terms of $\mathrm{MgO}(7.9 \pm 0.9 \mathrm{wt} \%$, excluding highly olivinephyric lavas (Data Set S1)) and thus derive from melts that have undergone similar amounts of differentiation. Their incompatible trace element (ITE) abundances and ratios (Data Set S1) show significant variations from normal mid-ocean ridge basalts $(\mathrm{NMORB})\left([\mathrm{La} / \mathrm{Sm}]_{\mathrm{N}}<1\right.$, with $\mathrm{N}$ : chondrite normalization after McDonough and Sun [1995]) to alkali basalt values $\left([\mathrm{La} / \mathrm{Sm}]_{\mathrm{N}}\right.$ up to 3.4 (Figure $2 \mathrm{c})$ ). The entire range in $[\mathrm{La} / \mathrm{Sm}]_{\mathrm{N}}$ is observed for $\mathrm{MgO} \sim 8 \mathrm{wt} \%$. Thus, the variability of $[\mathrm{La} / \mathrm{Sm}]_{\mathrm{N}}$, used as an index for the degree of enrichment of the lavas, cannot be accounted for by fractional crystallization and is inherited from distinct parental magmas. A similar range of $[\mathrm{La} / \mathrm{Sm}]_{\mathrm{N}}$ variations is not observed along the segment [Mahoney et al., 1989; Murton et al., 2005; Nauret et al., 2006] suggesting that along-axis samples are not representative of the entire geochemical range of lavas erupted during a relatively short time interval.

[9] Isotope compositions define two groups that are independent of the geographical distribution of the samples along the profile (Figure 2d). Differences in the radiogenic $\mathrm{Sr}$ isotope composition of the two groups cannot be attributed to seawater contamination (increasing ${ }^{87} \mathrm{Sr} /{ }^{86} \mathrm{Sr}$ at constant ${ }^{143} \mathrm{Nd} /{ }^{144} \mathrm{Nd}$ ). Samples are very fresh, with LOI values generally $<$ 0.7 wt $\%$ and we did not identify any mineralogical evidence for secondary alteration. Furthermore, rock powders were acid leached prior to $\mathrm{Sr}-\mathrm{Nd}$ isotope analyses in order to remove any seawater-derived $\mathrm{Sr}$ component. For two samples from both groups, leaching and measurements were duplicated. Comparison of the ${ }^{87} \mathrm{Sr} /{ }^{86} \mathrm{Sr}$ ratio of the original and duplicate measurements (Data Set S1 and Figures 2d and 3 ) demonstrates that leaching was efficient.

[10] The different isotopic signatures of the two groups mimics those observed for the Rodrigues Island and the Rodrigues and Gasitao Ridges. Lavas from Group 1 (9 samples) have high ${ }^{87} \mathrm{Sr} /{ }^{86} \mathrm{Sr}$ for a given ${ }^{143} \mathrm{Nd} /{ }^{144} \mathrm{Nd}$ (Figure 3) and define the depleted extension of the Rodrigues and Gasitao Ridges isotopic trends. Group 1 samples also have moderate ITE enrichments $\left([\mathrm{La} / \mathrm{Sm}]_{\mathrm{N}}<1\right.$ (Data Set S1 and Figure 1b)) which are decoupled from isotope ratios (Figure 4a). This signature is similar to that of some samples from the Gasitao Ridge and from the CIR axis (Gasitao Group described by Nauret et al. [2006] which have been related to the local contamination of the CIR mantle by the Réunion plume [Mahoney et al., 1989; Murton et al., 2005; Nauret et al., 2006]. The association of depleted trace element patterns with an isotopically enriched mantle source has been related to a high degree of partial melting of the contaminated CIR mantle [Nauret et al., 2006]. In contrast, $\mathrm{Sr}-\mathrm{Nd}$ isotope ratios of Group 2 lavas (16 samples) extend the Rodrigues Island isotopic field toward depleted compositions. The degree of ITE enrichment reached by Group 2 samples (Data Set S1) is exceptional in a spreading context (similar to that of Macquarie Island lavas [Kamenetsky and Maas, 2002]) and correlates strongly with isotope ratios (Figure 4a). We propose that the geochemical signature of Group 2 lavas derives from mixing between the CIR mantle and a Rodrigues Island-like component (Figure 3).

[11] When plotted along the across-axis profile, the ITE and isotope ratio variations define sawtooth patterns (Figures 2c and 2d). The enriched spikes 


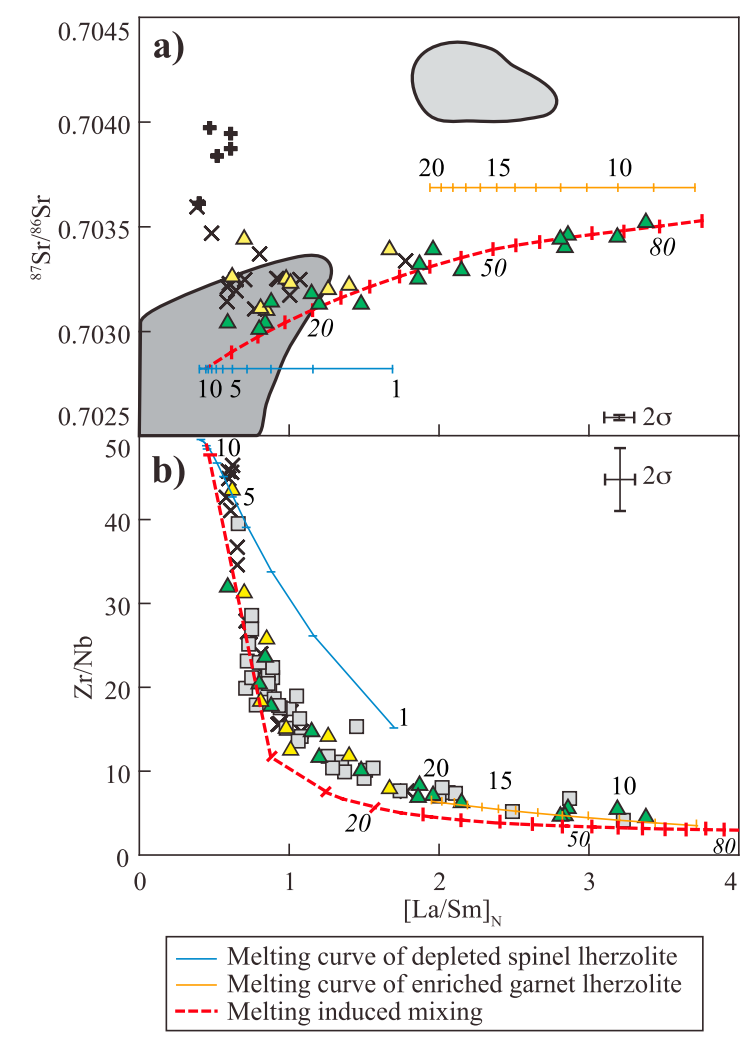

Figure 4. Geochemical characteristics of Group 2 lavas: (a) ${ }^{87} \mathrm{Sr} /{ }^{86} \mathrm{Sr}$ versus $[\mathrm{La} / \mathrm{Sm}]_{\mathrm{N}}$ and (b) $\mathrm{Zr} / \mathrm{Nb}$ versus $[\mathrm{La} / \mathrm{Sm}]_{\mathrm{N}}$. The standard deviation is $2 \sigma$. Mantle source composition, partition coefficients, and solid and liquid modes used for melting curve calculations are listed in Table 1. Our data are well reproduced considering the progressive dilution (from $60 \%$ to $0 \%$ ) of the low-degree enriched melts $(\mathrm{F}=2 \%)$ in the aggregated liquids due to their mixing with melts issued from higher degree of melting $(F=10 \%)$ of the depleted component. Symbols are as in Figure 3.

distribute regularly through time and symmetrically on the African and Indian plates (Figures 2c and 2d). The amplitude of the enriched spikes is not strictly identical on the both sides, which may be due to the sampling resolution. This distribution reveals that primary melts with strong ITE and isotope enrichments have been periodically emplaced at the axis in the past, with an estimated time interval of 150-200 kyr. The estimated periodicity is similar to that of tectonomagmatic cycles deduced from fault spacing on the very slow Southeast Indian Ridge and related to variations of melt supply from the mantle to the crust [Sauter et al., 1991]. On the eastern side of the profile, three of the enriched spikes occur near major faults (Figures 2a and 2c). This spatial association may suggest that the erup- tion of enriched melts is broadly synchronous with periods of low magma supply.

\section{Mantle Heterogeneity and Melting Regime Beneath the CIR}

[12] The isotopic variability observed along the profile argues for a compositionally heterogeneous mantle source beneath the CIR. The melting of a heterogeneous mantle at constant degree of melting is not able to generate the observed amplitude of variations of ITE ratios, with the exception of the very low degrees of melting that are clearly not associated with normal ridge spreading. The continuous trend from NMORB to ITE enriched compositions observed in Figure $4 \mathrm{~b}$ implies a common genetic mechanism for the depleted and enriched lavas, through a combination of mantle processes varying progressively with time and coupling source composition and variations in degree of melting.

[13] To resolve the chemical effects of melting and source heterogeneity, we considered ratios involving moderately ITE ( $\mathrm{Zr}$ and $\mathrm{Sm}$ ) that are dominantly influenced by the melting process, and highly ITE ( $\mathrm{La}$ and $\mathrm{Nb}$ ) that will dominantly reflect source heterogeneity [Stracke and Bourdon, 2009]. Our data are compared with theoretical aggregated melts resulting from mixing between enriched and depleted melts, produced by variable melting degrees of enriched and depleted sources, respectively (Figure 4). It is beyond the scope of this study to perform a systematic exploration of all partial melting and source composition/structure scenarios. For the depleted end-member, we used the typical composition of a spinel-lherzolite and we utilized a garnet-bearing lithology for the enriched endmember because $[\mathrm{La} / \mathrm{Sm}]_{\mathrm{N}}$ positively correlates with $[\mathrm{Dy} / \mathrm{Yb}]_{\mathrm{N}}$, which is an indicator for melting in the garnet stability field (Table 1). Calculations used a fractional, nonmodal melting model (Table 1) in conjunction with a simple melt extraction model. We assumed that mantle components melt independently and that no reaction occurs between their derived melts. Differences in solidus temperature between the two sources result in a depth interval where low-degree garnet-lherzolite melts are produced and averaged before mixing with the spinel-lherzolite melts. Considering our assumptions about source composition, the large enrichment in $[\mathrm{La} / \mathrm{Sm}]_{\mathrm{N}}$ and depletion in $\mathrm{Zr} / \mathrm{Nb}$ observed in the most enriched lavas (Figure 4) are reproduced by mixing large amounts of the melts resulting from 
Table 1. Geochemical Compositions and Melting Parameters Used for Mantle Source Mixing and Melting Calculations

\begin{tabular}{|c|c|c|c|c|c|c|c|c|c|c|}
\hline & \multicolumn{8}{|c|}{ Composition of Mantle Components (Trace Element Contents in ppm) } & & \\
\hline & $\mathrm{Nb}$ & $\mathrm{La}$ & $\mathrm{Sr}$ & $\mathrm{Nd}$ & $\mathrm{Zr}$ & $\mathrm{Sm}$ & ${ }^{87} \mathrm{Sr} /{ }^{86} \mathrm{Sr}$ & ${ }^{143} \mathrm{Nd} /{ }^{144} \mathrm{Nd}$ & & \\
\hline$\overline{\mathrm{CIR}^{\mathrm{a}}}$ & 0.09 & 0.13 & 6.09 & 0.48 & 4.27 & 0.21 & 0.7025 & 0.5132 & & \\
\hline \multirow[t]{4}{*}{ Rodrigues Island $\mathrm{d}^{\mathrm{b}, \mathrm{c}}$} & 1.33 & 0.73 & 12 & 1.4 & 11.2 & 0.39 & 0.70369 & 0.512861 & & \\
\hline & \multicolumn{10}{|c|}{ Partition Coefficients and Melting Modes ${ }^{\mathrm{b}}$} \\
\hline & \multirow[b]{2}{*}{$\mathrm{Nb}$} & \multirow[b]{2}{*}{$\mathrm{La}$} & \multirow[b]{2}{*}{$\mathrm{Sr}$} & \multirow[b]{2}{*}{$\mathrm{Nd}$} & \multirow[b]{2}{*}{$\mathrm{Zr}$} & \multirow[b]{2}{*}{$\mathrm{Sm}$} & \multicolumn{2}{|c|}{ Spinel-Lherzolite } & \multicolumn{2}{|c|}{ Garnet-Lherzolite } \\
\hline & & & & & & & Sol. & Liq. & Sol. & Liq. \\
\hline Olivine & 0.0042 & 0.001 & 0.003 & 0.06 & 0.27 & 0.115 & 0.52 & 0.35 & 0.56 & 0.25 \\
\hline Opx & 0.007 & 0.042 & 0.096 & 0.19 & 0.128 & 0.28 & 0.3 & -0.1 & 0.12 & 0.14 \\
\hline $\mathrm{Cpx}$ & 0.0001 & 0.0005 & 0.009 & 0.007 & 0.013 & 0.01 & 0.18 & 0.75 & 0.27 & 0.53 \\
\hline Garnet & 0.00004 & 0.00005 & 0.008 & 0.0002 & 0.0013 & 0.0006 & & & 0.05 & 0.25 \\
\hline
\end{tabular}

${ }^{\mathrm{a}}$ Data from Workman and Hart [2005] and Nauret et al. [2006].

${ }^{\mathrm{b}}$ Data from Donnelly et al. [2004].

${ }^{\mathrm{c}}$ Data from Baxter et al. [1985].

low degree of melting ( $2 \%$ ) of the enriched peridotite and the melts resulting from larger degree of melting $(10 \%)$ of the depleted mantle. In this case, the continuous geochemical evolution toward depleted lavas, both in terms of ITE and isotope ratios (Figure 4), requires that the proportion of the low-degree enriched melts relative to the depleted melts significantly decreases over the melting column. In the melting regime, this combination can be achieved through two mechanisms: (1) mixing of variably enriched melt batches originating from different degrees of melting of a mantle heterogeneous on the scale of the melting column (the more fertile enriched component melts first and is diluted when melting proceeds) or (2) continuous change as melting proceeds of the paragenesis of a fine-scale heterogeneous source in which each mantle phase has a distinct isotopic composition (dynamic source [Kamenetsky and Maas, 2002]).

\section{Mantle Chemical Structure and Melt Extraction Dynamics}

[14] The contribution of mantle heterogeneities to the melting processes can be discussed in terms of two end-member scenarios: Scenario A consists of continuous production of enriched melts extracted from a small-scale heterogeneous source (Figure 5a). These melts should be periodically isolated and released from the melting region, following a time scale further constrained in this study of 150$200 \mathrm{kyr}$. This time scale is of the same order as that of melt extraction inferred from ${ }^{230} \mathrm{Th}$ excess in MORB [e.g., Jull et al., 2002]. Scenario B consists of recurrent periods of low melt productivity, with production of enriched liquids that rapidly ascend and reach the surface prior to mixing (Figure 5b). This second hypothesis successfully explains the association observed along the profile between enriched spikes and major faults formed during periods of low magma supply.

[15] In scenario $B$, the short-period variations in melt production cannot result from fluctuations in mantle dynamics, which require longer time scales: e.g., thermal pulses of first (10-20 Myr [Cipriani et al., 2009]) and second orders (3-4 Myr [Bonatti et al., 2003]); or change from active to passive flow (14 Myr [Coogan et al., 2004]). For an accretion rate of $42 \mathrm{~mm} / \mathrm{yr}$ [DeMets et al., 1990] and a passive mantle upwelling, the mantle passes through a $60 \mathrm{~km}$ high melting column in $3 \mathrm{Myr}$. Even if the connection between accretion rate and mantle upwelling velocity is probably not as straightforward, the discrepancy between the observed periodicity and this estimation is too large for changes in upwelling velocity to explain the difference in melt production. The variation of the melting degree may also result from the periodic introduction at the bottom of the melting column of fertile mantle (high density of enriched veins, blobs or layers), which melts preferentially. This vertically stratified mantle geometry (i.e., marble cake [Allègre and Turcotte, 1986; Polvé and Allègre, 1980]) (Figure 5b), would also explain the continuous trend that exists between depleted and enriched magmas (Figure 4b) and the observed connection between melting degree and source composition. Every 150$200 \mathrm{kyr}$, melting of an enriched layer starts at the base of the melting column, producing a spike, followed by the progressive dilution of the enriched signature as mantle ascends. By extrapolating the 


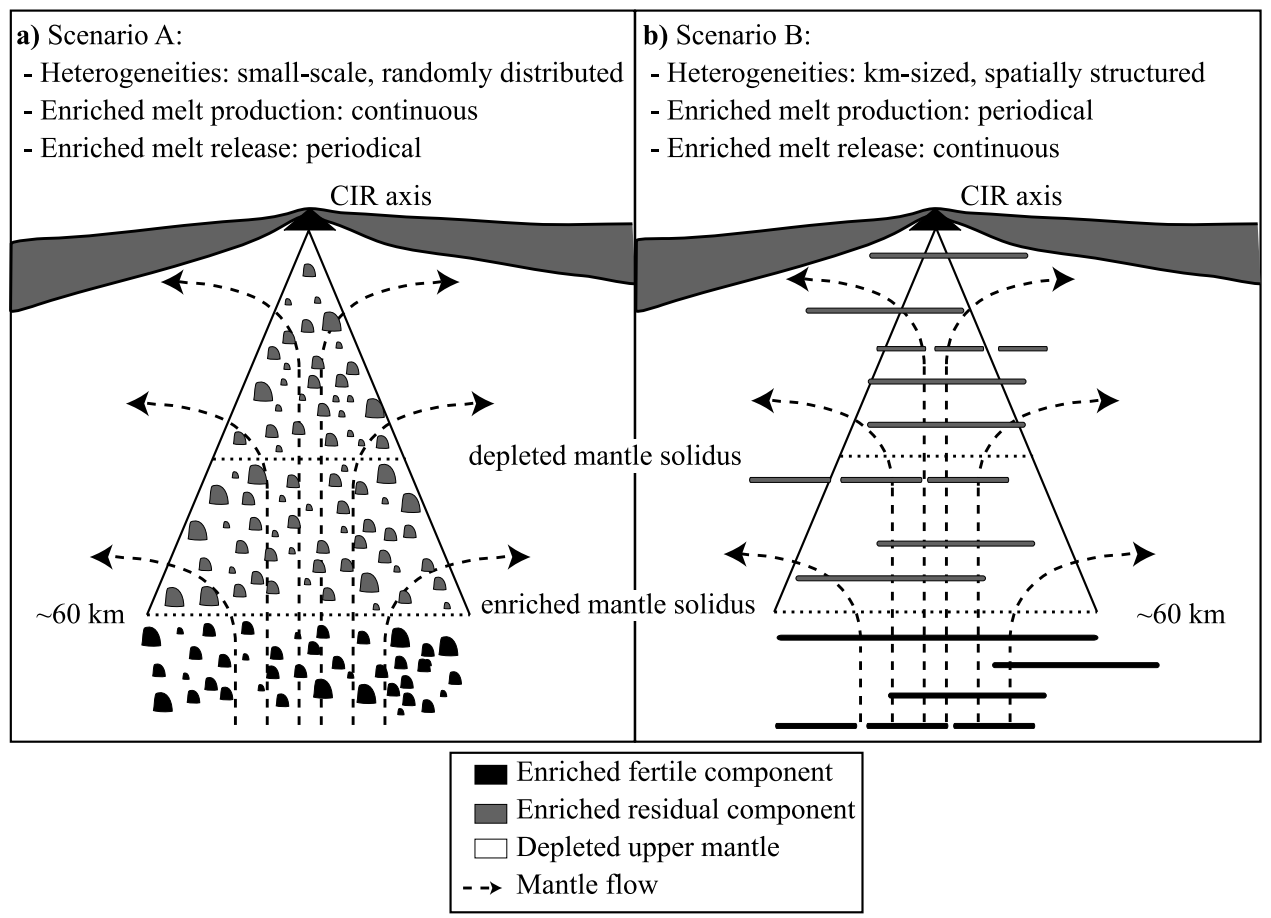

Figure 5. Schematic cross sections of the upper mantle beneath the CIR describing the distribution of the enriched mantle heterogeneities. The melt extraction and migration mechanisms (dunitic channels versus magmatic waves) are not depicted here as they can be applied to both cross sections. (a) In scenario A, enriched melts are continuously produced and at regular intervals reach the surface without mixing. (b) In scenario B, when a fertile component crosses its solidus, the first increments of enriched melts are pooled and reach the surface undiluted.

proportion of enriched lavas collected along the profile with the abundance of enriched material within the mantle, we propose that enriched domains represent at least $10 \%$ of the whole mantle processed in the melting column over $800 \mathrm{kyr}$ (Figure 5b). This is a lower limit because a significant fraction of the enriched melts did not reach the seafloor but mixed with depleted melts or crystallized within the crust. Considering the accretion rate as an upper estimate of the mantle upwelling velocity, we calculated the spacing between enriched domains to be around $3-4 \mathrm{~km}$ in the mantle.

[16] Scenario A describes the case of a mantle source in which heterogeneities are randomly distributed in space and size (Figure 5a). Production of enriched melts is therefore continuous and these melts should theoretically be diluted into the various melt increments to finally generate average MORB. On the contrary, episodic emplacement of enriched magmas on the seafloor implies that (1) these melts are pooled, isolated, and released following a process with a time scale of 150-200 kyr and (2) they should move to the surface without reacting with the surrounding mantle. Dunitic channels [Kelemen et al., 1995; Spiegelman and Kelemen, 2003] or magmatic waves [Rabinowicz and Ceuleneer, 2005; Rabinowicz and Toplis, 2009] may be a way to maintain liquids isolated from deeper region up to the base of the oceanic crust. Furthermore, the periodicity that we observe (150-200 kyr) could be accounted for by the distance between upwelling horizontal veins resulting from vertical compaction [Rabinowicz and Toplis, 2009].

\section{Conclusions}

[17] This study provides strong time constraints for magma generation and migration under oceanic ridges, calling for a process with a periodicity of 150-200 kyr. Our data set emphasizes that a large spectrum of the CIR geochemical signatures is observed along a flow line through a short time period. The across-axis approach brings further and complementary information relative to along-ridge geochemical studies of MORB. Melt extraction processes do not sample enriched sections of the mantle beneath oceanic ridges continuously. The governing factors for the occurrence of enriched signatures in the sampled lavas are (1) the relative abundance of enriched material, i.e., close to or far 
from a hot spot, their size, and spatial distribution, and (2) melt segregation and migration mechanisms. This conclusion questions the extent to which the chemical and isotopic ranges observed in erupted lavas are directly representative of their mantle sources and the proportions of depleted versus enriched lavas erupted on axis are representative estimates of the average MORB mantle composition.

\section{Acknowledgments}

[18] This research has been supported by IFREMER and INSU-CNRS through Programme National Dorsales. We thank Captain M. Houmard and the crew of R/V l'Atalante, the operation team of Nautile, and the GIMNAUT Scientific Party for their efforts during the GIMNAUT cruise. We are grateful to J. Cotten for performing the ICPAES analyses. Constructive discussions with G. Ceuleneer, M. Toplis, and M. Rabinowicz contributed to improve the manuscript. We thank Joel Baker for his editorial assistance and Andrea Stracke and an anonymous reviewer for reviewing this work. This is Institut de Physique du Globe de Paris contribution 2632.

\section{References}

Allègre, C. J., and D. L. Turcotte (1986), Implications of a twocomponent marble-cake mantle, Nature, 323, 123-127, doi: $10.1038 / 323123 \mathrm{a} 0$.

Baxter, A. N., B. G. J. Upton, and W. M. White (1985), Petrology and geochemistry of Rodrigues Island, Indian Ocean, Contrib. Mineral. Petrol., 89, 90-101, doi:10.1007/ BF01177594.

Bonatti, E., M. Ligi, D. Brunelli, A. Cipriani, P. Fabretti, V. Ferrante, L. Gasperini, and L. Ottolini (2003), Mantle thermal pulses below the Mid-Atlantic Ridge and temporal variations in the formation of oceanic lithosphere, Nature, 423, 499-505, doi: $10.1038 /$ nature 01594 .

Bosch, D., J. Blichert-Toft, F. Moynier, B. K. Nelson, P. Telouk, P. Gillot, and F. Albarède (2008), Pb, Hf and Nd isotope compositions of the two Réunion volcanoes (Indian Ocean): A tale of two small-scale mantle "blobs," Earth Planet. Sci. Lett., 265, 748-768, doi:10.1016/j.eps1.2007. 11.018 .

Briais, A. (1995), Structural analysis of the segmentation of the Central Indian Ridge between $20^{\circ} 30^{\prime} \mathrm{S}$ and $25^{\circ} 30^{\prime} \mathrm{S}$ (Rodriguez Triple Junction), Mar. Geophys. Res., 17, 431-467, doi:10.1007/BF01371787.

Briais, A., M. Maia, P. Gente, and J. Dyment (2001), Influence of the Reunion/Rodrigues hotspot on the structure of the Central Indian Ridge near $19^{\circ} \mathrm{S}$, Eos Trans. AGU, 82(47), Fall Meet. Suppl., Abstract T42C-0945.

Cipriani, A., E. Bonatti, D. Brunelli, and M. Ligi (2009), 26 million years of mantle upwelling below a segment of the Mid Atlantic Ridge: The Vema Lithospheric Section revisited, Earth Planet. Sci. Lett., 285, 87-95, doi:10.1016/ j.epsl.2009.05.046.

Coogan, L. A., G. M. Thompson, C. J. MacLeod, H. J. B. Dick, S. J. E. Edwards, A. Hosford Scheirer, and T. L. Terry
(2004), A combined basalt and peridotite perspective on 14 million years of melt generation at the Atlantis Bank segment of the Southwest Indian Ridge: Evidence for temporal changes in mantle dynamics?, Chem. Geol., 207, 13-30, doi:10.1016/j.chemgeo.2004.01.016.

DeMets, C., R. G. Gordon, D. F. Argus, and S. Stein (1990), Current plate motions, Geophys. J. Int., 101, 425-478, doi:10.1111/j.1365-246X.1990.tb06579.x.

Donnelly, K. E., S. L. Goldstein, C. H. Langmuir, and M. Spiegelman (2004), Origin of enriched ocean ridge basalts and implications for mantle dynamics, Earth Planet. Sci. Lett., 226, 347-366, doi:10.1016/j.epsl.2004.07.019.

Dyment, J., et al. (1999), The Magofond 2 cruise: A surface and deep-tow survey on the past and present Central Indian Ridge, InterRidge News, 8, 25-31.

Dyment, J., J. Lin, and E. T. Baker (2007), Ridge-hotspot interactions: What mid-ocean ridges tell us about deep Earth processes, Oceanography, 20, 102-115.

Gee, J., S. C. Cande, J. A. Hildebrand, K. Donnelly, and R. L. Parker (2000), Geomagnetic intensity variations over the past 780 kyr obtained from near-seafloor magnetic anomalies, Nature, 408, 827-832, doi:10.1038/35048513.

Guyodo, Y., and J. P. Valet (1999), Global changes in intensity of the Earth's magnetic field during the past $800 \mathrm{ky}$, Nature, 399, 249-252, doi:10.1038/20420.

Hanson, J. A., and J. R. Bowman (2005), Indian Ocean ridge seismicity observed with a permanent hydroacoustic network, Geophys. Res. Lett., 32, L06301, doi:10.1029/ 2004GL021931.

Honsho, C., J. Dyment, K. Tamaki, M. Ravilly, H. Horen, and P. Gente (2009), Magnetic structure of a slow spreading ridge segment: Insights from near-bottom magnetic measurements on board a submersible, J. Geophys. Res., 114, B05101, doi:10.1029/2008JB005915.

Jull, M., P. B. Kelemen, and K. W. W. Sims (2002), Consequences of diffuse and channelled porous melt migration on uranium series disequilibria, Geochim. Cosmochim. Acta, 66, 4133-4148, doi:10.1016/S0016-7037(02)00984-5.

Kamenetsky, V. S., and R. Maas (2002), Mantle-melt evolution (dynamic source) in the origin of a single MORB suite: A perspective from magnesian glasses of Macquarie Island, J. Petrol., 43, 1909-1922, doi:10.1093/petrology/43.10.1909.

Kelemen, P. B., N. Shimizu, and V. J. M. Salters (1995), Extraction of mid-ocean-ridge basalt from the upwelling mantle by focused flow of melt in dunite channels, Nature, 375, 747-753, doi:10.1038/375747a0.

Mahoney, J. J., J. H. Natland, W. M. White, R. Poreda, S. H. Bloomer, R. L. Fisher, and A. N. Baxter (1989), Isotopic and geochemical provinces of the western Indian Ocean spreading centers, J. Geophys. Res., 94, 4033-4052, doi:10.1029/ JB094iB04p04033.

McDonough, W. F., and S. S. Sun (1995), Composition of the Earth, Chem. Geol., 120, 223-253, doi:10.1016/0009-2541 (94)00140-4.

Mellor, S. H. (1998), The geochemistry, petrology and petrogenesis of the Rodrigues Ridge (western Indian Ocean), Ph.D. thesis, 297 pp., Univ. of Greenwich, London.

Murton, B. J., A. G. Tindle, J. A. Milton, and D. Sauter (2005), Heterogeneity in southern Central Indian Ridge MORB Implications for ridge-hotspot interaction, Geochem. Geophys. Geosyst., 6, Q03E20, doi:10.1029/2004GC000798.

Nauret, F., W. Abouchami, S. J. Galer, A. W. Hofmann, C. Hémond, C. Chauvel, and J. Dyment (2006), Correlated trace element $\mathrm{Pb}$ isotope enrichments in Indian MORB 
along $18-20^{\circ} \mathrm{S}$, Central Indian Ridge, Earth Planet. Sci. Lett., 245, 137-152, doi:10.1016/j.epsl.2006.03.015.

Pietruszka, A. J., E. H. Hauri, and J. Blichert-Toft (2009), Crustal contamination of mantle-derived magmas within Piton de la Fournaise Volcano, Réunion Island, J. Petrol., 50, 661-684, doi:10.1093/petrology/egp016.

Polvé, M., and C. J. Allègre (1980), Orogenic lherzolite complexes studied by ${ }^{87} \mathrm{Rb} /{ }^{87} \mathrm{Sr}$ : A clue to understand the mantle convection process?, Earth Planet. Sci. Lett., 51, 71-93, doi:10.1016/0012-821X(80)90258-7.

Rabinowicz, M., and G. Ceuleneer (2005), The effect of sloped isotherms on melt migration in the shallow mantle: A physical and numerical model based on observations in the Oman ophiolite, Earth Planet. Sci. Lett., 229, 231-246, doi:10.1016/j.epsl.2004.09.039.

Rabinowicz, M., and M. J. Toplis (2009), Melt segregation in the lower part of the partially molten mantle zone beneath an oceanic spreading centre: Numerical modelling of the combined effects of shear segregation and compaction, J. Petrol., 50, 1071-1106, doi:10.1093/petrology/egp033.

Sandwell, D. T., and W. H. F. Smith (1997), Marine gravity anomaly from Geosat and ERS 1 satellite altimetry, J. Geophys. Res., 102, 10,039-10,054, doi:10.1029/96JB03223.

Sauter, D., M. Munshy, H. Whitechurch, and E. Humler (1991), Periodicity in the accretion process on the Southeast Indian Ridge at $27^{\circ} 40^{\prime} \mathrm{S}$, Tectonophysics, 195, 47-64, doi:10.1016/0040-1951(91)90143-G.

Smith, W. H. F., and D. T. Sandwell (1997), Global seafloor topography from satellite altimetry and ship depth soundings, Science, 277, 1956-1962, doi:10.1126/science. 277.5334.1956.
Soule, S. A., D. J. Fornari, M. R. Perfit, M. A. Tivey, W. I. Ridley, and H. Schouten (2005), Channelized lava flows at the East Pacific Rise crest $9^{\circ}-10^{\circ} \mathrm{N}$ : The importance of off-axis lava transport in developing the architecture of young oceanic crust, Geochem. Geophys. Geosyst., 6, Q08005, doi:10.1029/2005GC000912.

Spiegelman, M., and P. B. Kelemen (2003), Extreme chemical variability as a consequence of channelized melt transport, Geochem. Geophys. Geosyst., 4(7), 1055, doi:10.1029/ $2002 \mathrm{GC} 000336$.

Stracke, A., and B. Bourdon (2009), The importance of melt extraction for tracing mantle heterogeneity, Geochim. Cosmochim. Acta, 73, 218-238, doi:10.1016/j.gca.2008.10.015.

Suganuma, Y., T. Yamazaki, T. Kanamatsu, and N. Hokanishi (2008), Relative paleointensity record during the last $800 \mathrm{ka}$ from the equatorial Indian Ocean: Implication for relationship between inclination and intensity variations, Geochem. Geophys. Geosyst., 9, Q02011, doi:10.1029/2007GC001723.

Vlastélic, I., C. Deniel, C. Bosq, P. Télouk, P. Boivin, P. Bachélery, V. Famin, and T. Staudacher (2009), Pb isotope geochemistry of Piton de la Fournaise historical lavas, J. Volcanol. Geotherm. Res., 184, 63-78, doi:10.1016/j. jvolgeores.2008.08.008.

Workman, R. K., and S. R. Hart (2005), Major and trace composition of the depleted MORB mantle (DMM), Earth Planet. Sci. Lett., 231, 53-72, doi:10.1016/j.epsl.2004. 12.005 . 